\title{
Gorilla conservation in Zaire
}

\author{
Conrad Aveling and Rosalind Aveling
}

The Zaire Gorilla Conservation Project was launched in 1984 after the 1981 census of mountain gorillas in the Virungas showed how the Mountain Gorilla Project in Rwanda, in which FFPS was closely involved, had helped to swell numbers. Over the past few years the Zaire project has made encouraging progress. The 1986 census counted the highest number of gorillas since the early 1970 s and some of that increase can be attributed to improved protection in Zaire. In addition, the park is benefiting from income from tourists visiting habituated gorilla groups. The project continues to extend, taking in eastern lowland gorillas and chimpanzees, as well as developing an overall education programme for the region around the park.

The first national park in Africa was created in 1925 to protect the mountain gorillas of the Virunga volcanoes. Later the area was formally divided between Rwanda and Zaire, retaining national park status as Rwanda's Parc des Volcans and the Parc National des Virunga in Zaire. The Parc National des Virunga (Figure 1) was extended in 1935 to $8000 \mathrm{sq} \mathrm{km}$, covering an extraordinary diversity of habitats from the Ruwenzori mountains through tropical rain forest to savannah, lakes and both active and extinct volcanoes. Mountain gorillas are confined to the 375-sq-km area of forest on the six extinct volcanoes shared with Rwanda and Uganda of which $225 \mathrm{sq} \mathrm{km}$ are in Zaire's Parc National des Virunga. The altitudinal range of the sector of the park in which gorillas occur is from $2000 \mathrm{~m}$ to $4500 \mathrm{~m}$ and includes a variety of habitats from Neobutonia forest at the lower altitudes through bamboo stands and Hagenia forest to giant Lobelia and Senecio at the highest altitudes in the sub-alpine zone, where gorillas have been recorded as high as $3800 \mathrm{~m}$.

\section{The Zaire Gorilla Conservation Project}

The Zaire Gorilla Conservation Project was launched in 1984-a collaborative effort between Zaire's Institut Zairois pour la Conservation de la Nature (IZCN), the Frankfurt Zoological 64
Society (FZS) and WWF/IUCN. The primary aim was to improve protection of the Virunga mountain gorilla Gorilla gorilla beringei in Zaire's Parc National des Virunga, although the project also aimed to update information on the conservation status of the more numerous eastern lowland subspecies of gorilla G.g. graueri. During the first three years FZS provided 93 per cent of the funding and WWF 7 per cent. With the launching of the WWF-funded education programme in 1987 the WWF contribution increased to 36 per cent.

As with the Rwandan MGP (regularly reported on in Oryx) the Zaire Gorilla Conservation Project has combined logistic assistance to the park with the development of a controlled tourism programme based on gorilla viewing. The latter has not only provided a greatly increased income for the park and an economic argument for its protection, but has also provided surveillance for a large area of the park with four of the largest families of gorillas being monitored daily.

The guard post of Jomba close to the Ugandan border at $2000 \mathrm{~m}$ has become the focus of the gorilla tourism programme. Here three families of gorillas have been habituated, two of which were opened for controlled tourism in September 1985 and October 1986, respectively. The third is under constant surveillance when in

Oryx Vol 23 No 2, April 1989 
Zaire, but sometimes ranges into Uganda; thus visits cannot be reserved in advance and are only available at short-notice when the family is in Zaire. A fourth family of gorillas at Bukima guard

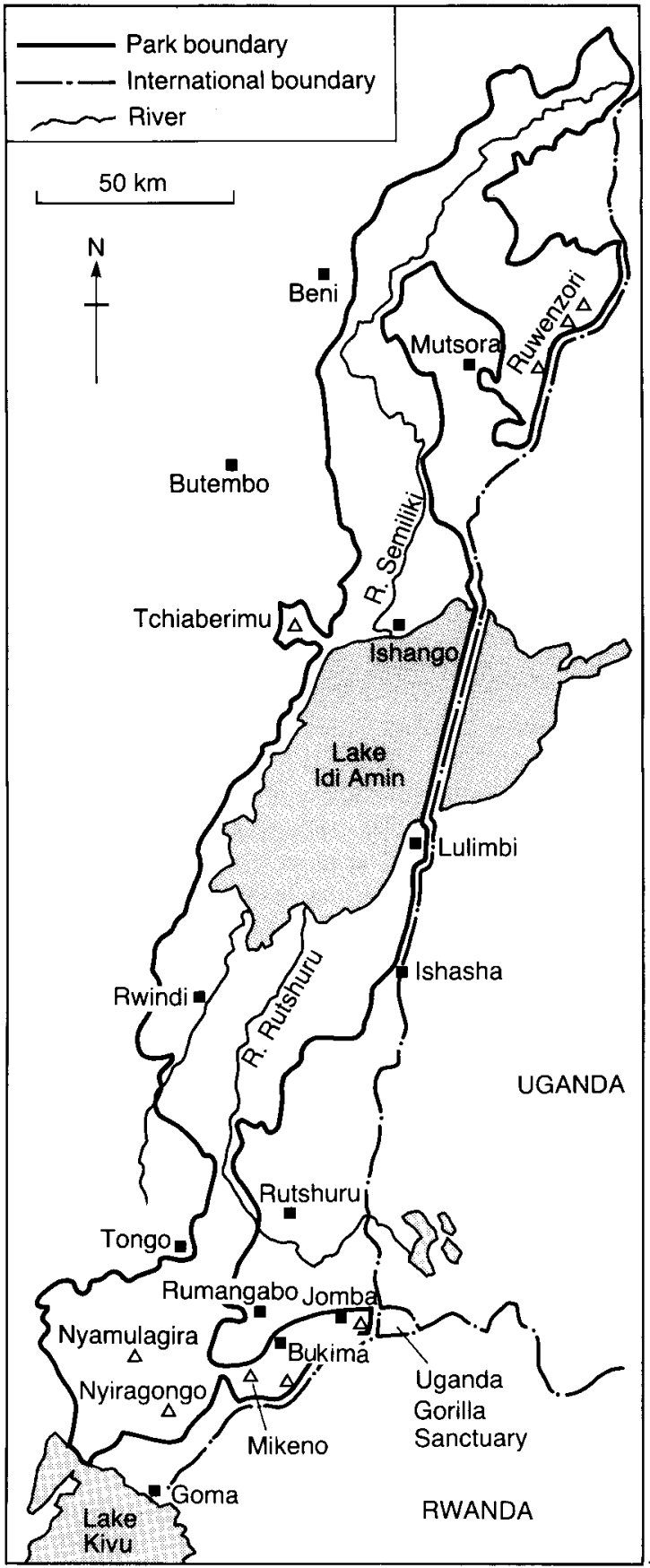

Figure 1. Parc National des Virunga

Gorilla conservation in Zaire post has been receiving visitors since June 1987 . To maximize the quality of the visit, while at the same time minimizing disturbance to the animals, only six visitors per family of gorillas per day are permitted and so a reservation system, co-ordinated through the IZCN office in Goma, has been set up to deal with the great demand for places (IZCN Bureau de Liaison, BP 660, Goma, Kivu, Zaire).

Within a period of just three years since the opening of tourism to gorillas in the southern sector of the Parc National des Virunga, park receipts have increased dramatically from zero to around $£ 23,000$ per month during peak tourist periods. The limit of six visitors per gorilla family in one daily visit has become firmly established and is insisted on by IZCN. Under the present parks administration these receipts go directly into improving facilities and management of national parks.

In addition to the tourism programme the project has provided considerable logistic support to improve park protection in general. A network of radios has improved communications and the guards of the southern sector of the park have been provided with uniforms, boots, warm clothing, sleeping bags, rucksacks and waterproofs. A programme of more regular patrols has been instigated with the project providing rations. Additional patrols are concentrated outside the tourism areas as the latter are avoided by poachers once the presence of guards and tourists becomes established. Many hundreds of wire snares, which are set by poachers to catch antelope but which are often responsible for mutilations or death of gorillas, have been removed from the park. At the start of the project both the northern and southern sectors of the park had no running vehicles and so two Land Rovers and two lorries have been provided. The project also has a programme of construction (guard houses and visitor cabins) building work being undertaken by park staff.

The project's achievements result from a productive working relationship between the national authority and international conservation groups. The emphasis has been on provision of expertise and funding as and when necessary to assist $\mathrm{IZCN}$ in development and management of their 


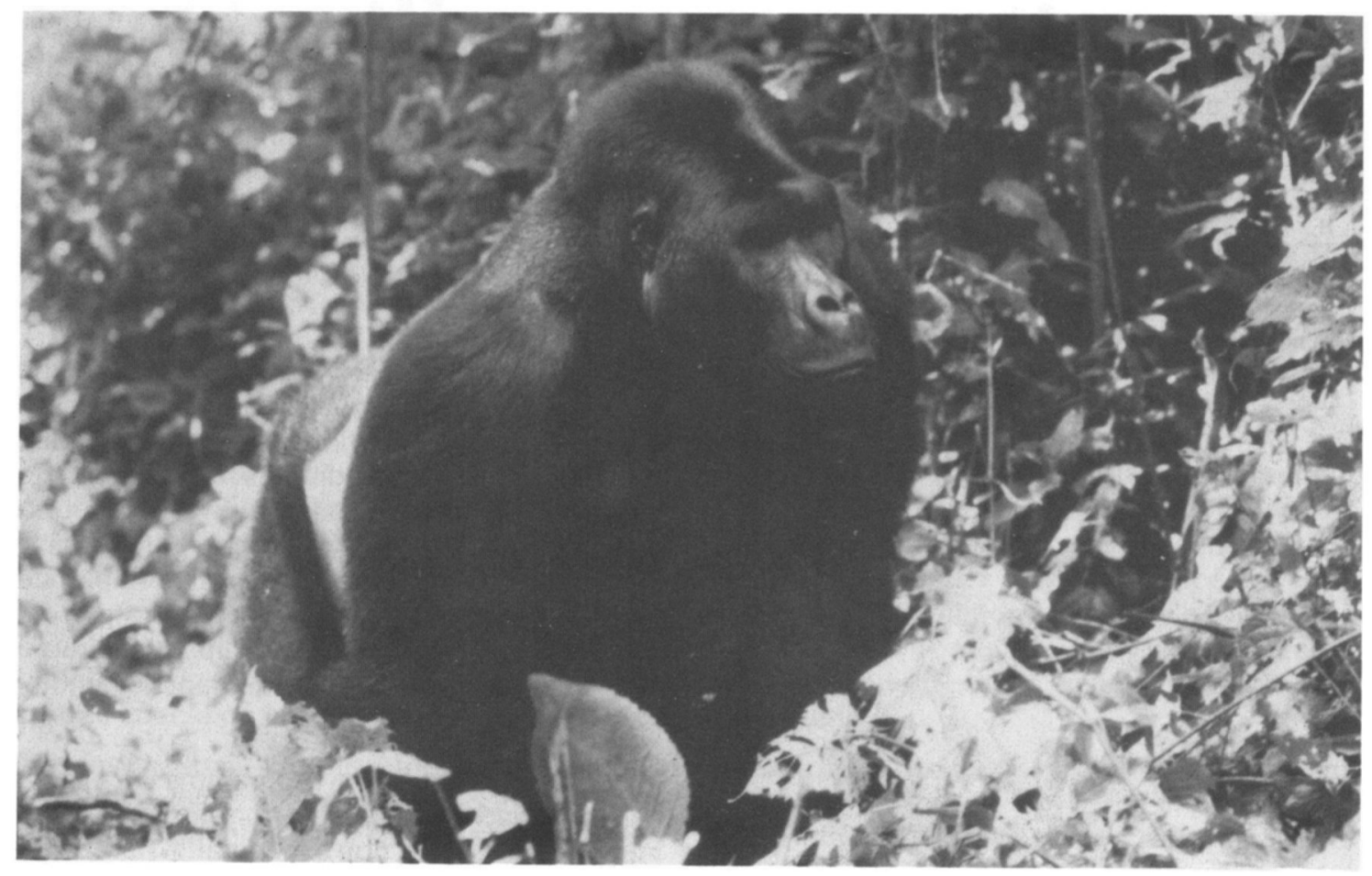

A silverback (C. and R.J. Aveling).

resources, setting up systems that will continue after the withdrawal of such assistance. Since establishing the gorilla tourism system the expatriate personnel have gradually withdrawn from its operation and concentrate most effort on developing other aspects of the project. The gorilla guides and trackers trained by the project have given on-the-job training to new guides taken on by IZCN, and two of the four gorilla families were habituated by guides and trackers themselves after training in approaches and techniques.

\section{Effect of the conservation work in the Virungas}

In 1981 a census of the entire Virunga mountain gorilla population of Zaire, Rwanda and Uganda counted 242 animals giving an estimated population size of between 242 and 266 (Aveling and Harcourt, 1983). That census confirmed the continuing decline of the population since Schaller's stud!' in 1960 (Schaller, 1963). However, the census also showed that the gorilla population in the Rwandan sector of the Virungas appeared to 66 have stabilized following the improved protection afforded by the activities of the Mountain Gorilla Project in that country and that the continuing overall decline was explained mainly by inadequate protection on the Zaire side of the volcanoes, an area encompassing roughly twothirds of the gorilla habitat.

To continue the regular monitoring of mountain gorillas, the Zoological Societies of New York and Frankfurt organized a census of the Virunga population in May and June 1986 (Vedder and Aveling, 1986). The methods used were the same as in previous censuses and the results are regarded as an almost complete count of the population, at most a 10 per cent underestimate. By co-ordinating the census such that teams worked simultaneously on both sides of the borders in a sweep from one end of the volcanoes to the other, it was possible to shorten the time period and minimize the possibility of counting the same group twice.

Briefly, the method involved 11 teams of workers (each with a team leader experienced in Oryx Vol 23 No 2, April 1989 
gorilla census techniques)* systematically covering sectors of the parks and examining night nest sites less than one week old. Since gorillas defecate in their nests at night and dung bolus size is correlated with animal age, examination of dung in the nests gives a good indication of the number, and age-class, of the animals in the group, although dung of infants less than one year old is usually missed. Additional data from the continuously monitored groups of Karisoke Research Centre and the Rwandan and Zaire Mountain Gorilla Projects were also used but, for consistency, infants of less than one year were omitted from calculations of percentages of immatures.

The results from the census were very encouraging. A total of 279 individuals were counted of which 11 were lone males and 268 were in 29 families. This gives an estimated upper limit of 307 and a mean estimate of 293 . The percentage of immatures within groups was 44.8 and mean group size was 9.2 .

These figures compare very favourably with census results of 1971-73 (Harcourt et al., 1981), 1976-78 (Weber and Vedder, 1983) and 1981 (Aveling and Harcourt, 1983). Indeed the number counted in the 1986 census is higher than any of the population estimates calculated from these earlier censuses (Table 1) indicating that the population is no longer declining and may even, for the first time since the early 1970s, be increasing.

*Amy Vedder (New York Zoological Society); Conrad Aveling, Gapira Mutazimiza, Mike Catsis (Frankfurt Zoological Society); David Watts (Karisoke Research Centre); Ingrid Steurs, Bernard de Wetter, Mark Condiotti (African Wildlife Foundation); Nyamuhinga Alois (ORTPN); Peter Trenchard (US Peace Corps-Burundi); Nicole Monfort (Independent-Rwanda).

Table 1. Comparison of gorilla census results

\begin{tabular}{lllllll}
\hline Census & $\begin{array}{l}\text { Total } \\
\text { counted }\end{array}$ & $\begin{array}{l}\text { No. of } \\
\text { groups }\end{array}$ & $\begin{array}{l}\text { Lone } \\
\text { males }\end{array}$ & $\begin{array}{l}\%^{*} \\
\text { immatures }\end{array}$ & $\begin{array}{l}\text { Total } \\
\text { estimated (range) }\end{array}$ & $\begin{array}{l}\text { Mean } \\
\text { group size }\end{array}$ \\
\hline $1971-73$ & 261 & 31 & 15 & 39.8 & $274(260-290)$ & 7.9 \\
$1976-78$ & 252 & 28 & 6 & 35.8 & $268(252-285)$ & 8.8 \\
1981 & 242 & 28 & 5 & $39.9(38.4)$ & $254(242-266)$ & 8.5 \\
1986 & 279 & 29 & 11 & $48.1(44.8)$ & $293(279-307)$ & 9.2
\end{tabular}

*\% immatures is calculated from the population counted in groups and includes infants of less than one year for consistency of comparison over the 15-year period. Thus the high figure for 1986 partly reflects the fact that more groups than ever before are monitored daily. Figures in parentheses exclude infants of less than 1 year and therefore avoid this bias.

Gorilla conservation in Zaire
Even more encouraging is the fact that the percentage of immature gorillas has increased to 44.8 per cent, the highest figure since the early 1970 s and up 6.4 per cent from 1981. (Omitting from these calculations infants of less than one year, which are known from monitored families but generally missed in non-monitored families, avoids bias since with the Zaire Gorilla Conservation Project now in operation more families than ever before are monitored daily. If infants of less than one year are included the figure is 48.1 per cent). Average group size at 9.2 is also the highest since the early 1970s and is yet another indication of a reproductively healthier population.

Of the 29 gorilla families, 16 may be regarded as well protected since they are either monitored daily by research workers and/or either of the tourism progammes, or they range almost entirely within the sectors in which these two activities take place. The percentage of immatures in these 'protected' families is 46.6 per cent compared with 41.7 per cent in the less well protected families; the 1981 figures were 48.5 per cent and 33.0 per cent respectively, indicating that there has been a substantial improvement in protection outside of the areas of regular monitoring by tourism and research.

The ranges of at least seven gorilla families straddle the international boundaries and may be regarded as 'shared' families. If, for the purpose of calculation, these shared families are divided between Zaire and Rwanda (no family uses Uganda exclusively) it is possible to compare the immature ratios between the countries. The figures are surprising-39.8 per cent for Rwanda and 47.8 per cent for Zaire compared with figures in 1981 of 44.0 per cent and 33.0 per cent 


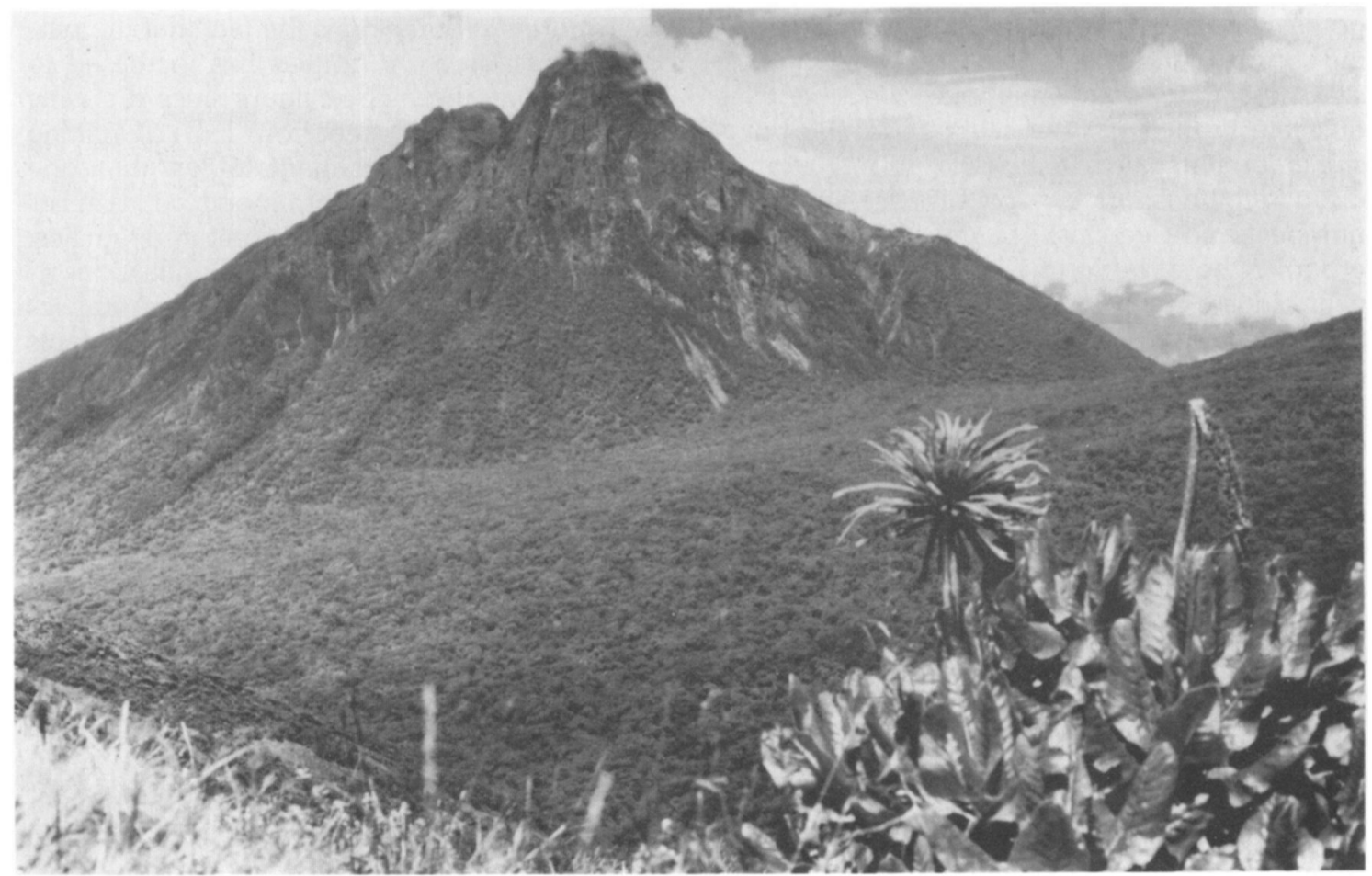

Mikeno volcano: the area most in need of protection (C. and R.J. Aveling).

for Rwanda and Zaire, respectively. Even if all shared families are apportioned to Rwanda together with a further four families that range in Zaire on or very close to the northern and western flanks of Visoke mountain (falling under the protective umbrella of the Rwandan MGP and Karisoke Research Centre), the figures still show a higher immature percentage for Zaire at 46.4 per cent compared with 44.4 per cent for Rwanda. While it is evident that part of the improvement in Zaire is due to increased protection, it is likely that the figures are also considerably affected by a series of natural demographic changes that took place in Rwanda between 1983 and 1986, which were monitored by the Karisoke Research Centre.

Three Rwandan families disintegrated in 1985 and 1986 ('Nunkie', 'New Group' and 'Group 6') following the natural deaths of the silverbacks and it is thought that almost all the animals transferred to neighbouring groups in Zaire. The monitored families 'Beetsme' and 'Peanuts', which range in Zaire, received at least six 68 juveniles and four subadults. No gorillas from 'Group 6' reappeared in any of the Rwandan families, which means that they must have moved to Zaire or died. Furthermore, when the two Rwandan families 'Mudakama' and 'Susa' merged in 1983 there were probably some infanticides.

As in 1981 the areas most in need of better protection are the Mikeno region in Zaire and the Gorilla Sanctuary of the Ugandan sector. In 1986 a mere 16 individuals were found on the mountain of Mikeno (along with very frequent signs of poaching) compared with 66 in 1981 . However, there was a corresponding increase in the number of gorillas found in the flatter areas north and north-east of the mountain. This is an area that was in the past much frequented by poachers, but which may now be better protected as a result of increased Zairian patrols in the area. Although the Ugandan sector is only 30 sq $\mathrm{km}$ in area there was evidence that at least 29 gorillas (10.4 per cent of the population) occasionally use the area and so, as has frequently

Oryx Vol 23 No 2, April 1989 


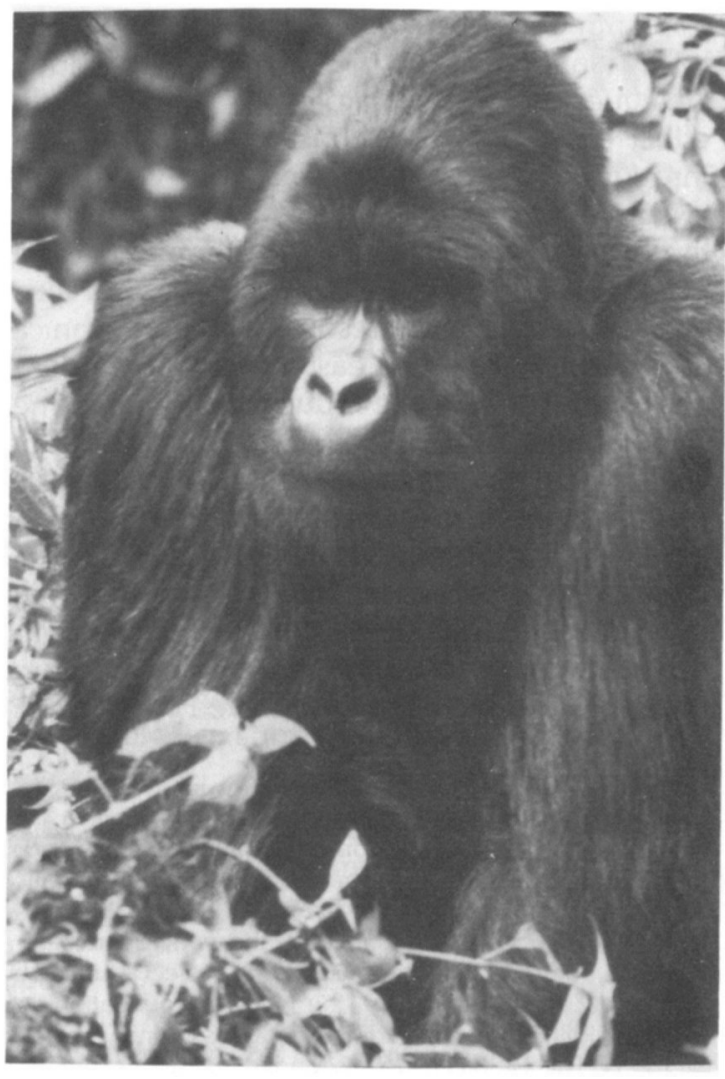

A male mountain gorilla (C. and R.J. Aveling).

been pointed out, it is very important that this area be better protected.

\section{Current work of the Zaire Gorilla Conservation Project}

\section{Gorillas}

The Gorilla Programme continues to pay trackers and trail cutters until this is taken over by IZCN, to fund and undertake constructions at the guard posts and to monitor developments with IZCN. It assists in improving the operation, particularly the vital radio network, and in sorting out problems together with IZCN as they arise. While some further consolidation is required, the gorilla tourism programme is becoming selfsufficient.

Other aspects of the gorilla conservation work in the Parc National des Virunga require further attention, however, notably the further improvement of protection measures in the Mikeno Gorilla conservation in Zaire sector, and additional support to IZCN for protection of the Tchiaberimu population of Gorilla gorilla graueri. The project is also trying to stimulate and facilitate survey work and conservation measures for G.g. graueri occurring in Maiko and Kahuzi-Biega National Parks where large populations still exist but details on their status are lacking.

\section{Chimpanzees}

Since 1986 the project has been preparing the ground for a chimpanzee conservation programme in the Parc National des Virunga, and this got under way during 1987, focusing on the Tongo region of the park's southern sector. Frankfurt Zoological Society, with funding from the Messerli Foundation, is supporting a field assistant to undertake habituation of chimpanzees and training of $I Z C N$ guides to develop a tourism programme with the same conservation aims as that for gorillas. The forest both within the park and particularly in the buffer zone around it (forêt domaniale) is seriously threatened by charcoal exploitation and a successful tourism programme is one of the most effective ways of preventing this illicit exploitation and thus protecting the habitat. Already the attention the project has concentrated on the area has helped reduce illegal forest destruction.

The forest is on an ancient chaotic lava flow where walking can be very tiring and dangerous, so a dense trail network is being established in the study area to facilitate movement about the terrain by the habituators, and eventually tourists, particularly in view of the long distances that chimpanzees cover and their speed of travel. It is anticipated that chimpanzees will take longer to habituate than gorillas and that a different system of visiting will have to be developed, which takes into account the constraints of their particular habitat and social system; however, it is hoped that IZCN could start to offer chimpanzee viewing during 1989 if the habituation progresses well.

\section{Environmental education}

In January 1987 the project launched an environmental education programme in the area around the Parc National des Virunga, funded by WWF. An experienced education officer working 
with IZCN counterparts at all levels has developed an ambitious programme with three main target groups - the rural population living around the park, primary and secondary schools, and political and social leaders. In order to identify the problems, and establish a base from which to evaluate the education work, he first conducted an extensive survey in five communities around the park, and this is providing a wealth of information to guide the development of the education programme.

In order to undertake the survey a team of 35 interviewers and co-ordinators were selected from the villages and trained in techniques, and the aim is that some of these could eventually become part of a network of village conservation action leaders. A major focus of the programme is to encourage small-scale development activities in the villages, which will be of direct benefit to both people and park, such as establishment of tree-nurseries and reforestation. One of the interviewers has been given basic training in forestry techniques and is tackling the critical area of conflict over wood exploitation between population and park. The co-operation of various development agencies is being obtained for this aspect of the programme, which will need greater resources than are currently available.

Although a series of seminars and lectures was held in 1987, the major emphasis in schools and other education establishments was delayed until a Land Rover equipped with audio-visual facilities arrived in 1988. Meanwhile, the first edition of an environmental magazine Kacheche, on the wood problem and forest conservation, has been prepared for publication and tested with children and adults of different educational levels throughout the region.

\section{The future}

Since 1984, when the joint IZCN/FZS/WWF project started its work in eastern Zaire, there has been a marked improvement in the management of national parks in the region. International cooperation projects such as this have been able to work and achieve their aims in an atmosphere of professionalism and optimism despite the many practical problems and hurdles such field projects face. This can be attributed largely to the 70 appointment of a dynamic and dedicated Director of National Parks in April 1985-President Délégué Général Mankoto ma Mbaelele; the effect of his firm and constant direction is felt throughout the parks service from Chief Park Wardens to junior guards. It is very satisfying that the project has been able to withdraw partially from the mountain gorilla conservation programme and turn its resources, both technical and financial, towards eastern lowland gorillas, chimpanzees and the education programme, which will act as the glue to consolidate all the work within the park. The Institut Zairois pour la Conservation de la Nature faces enormous problems and urgently needs the help of international organizations in its task of preserving the great diversity of habitats and species under its care, and such organizations can now invest in nature conservation in Zaire with renewed confidence.

\section{Acknowledgments}

The Governments of Zaire, Rwanda and Uganda, and in particular their departments of conservation and national parks, (l'Institut Zairois pour la Conservation de la Nature, Office Rwandais du Tourisme et des Parcs Nationaux, Uganda Game and Forest Department) made the work reported here possible. The Zaire Gorilla Conservation Project is funded by Frankfurt Zoological Society, the Messerli Foundation and World Wildlife Fund, with administrative assistance provided by IUCN. The 1986 census was funded by the Frankfurt and New York Zoological Societies, the USAID Ruhengeri Resource and Management Project, the Digit Fund and World Wildlife Fund. We would particularly like to thank Dr R. Faust, President of Frankfurt Zoological Society, for his continued support and encouragement, and the fieldworkers who have all contributed to the project's achievements in Zaire, notably Conservateur en Chef Makabuza Kabirizi, Brigadier Chef Mburanumwe Sylvestre, Project Assistant Gapira Mutazimiza, Education Officer Drs Jaap Schoorl and Chimpanzee Programme Leader Drs Annette Lanjouw.

\section{References}

Aveling, C. and Harcourt, A.H. 1984. A census of the Virunga gorillas. Oryx, 18, 8-13.

Harcourt, A.H., Fossey, D. and Sabater Pi, J. 1981. Demography of Gorilla gorilla. J. Zool., Lond., 195, 215-233.

Schaller, G.B. 1963. The Mountain Gorilla. University of Chicago Press, Chicago.

Vedder, A. and Aveling, C. 1986. Census of the Virunga Population of Gorilla gorilla beringei. Co-ordinators' report, September 1986. Mimeo (French and English).

Weber, A.W. and Vedder, A. 1983. Population dynamics of the Virunga Gorillas: 1959-1978. Biol. Conserv., 26, 341-366.

Conrad Aveling and Rosalind Aveling, Frankfurt Zoological Society, Alfred-Brehm Platz 16, D-6000 Frankfurt/Main 1, FRG.

Oryx Vol 23 No 2, April 1989 